\title{
Pawel Laniewski
}

University of Silesia

\section{The Language of a Minority- Horst Bienek's The First Polka in the Context of Minor Literatures}

\begin{abstract}
The interest in minor literatures - as described by Gilles Deleuze and Félix Guattari on the basis of an analysis of Franz Kafka's works - occupy a special place in contemporary literary life. Minority, expressed in different ways, is not only limited to political and social relations between a representative of a minority and the dominant culture, but also translates into a wide ontological field, responsible for the development of a different cognitive apparatus and numerous modifications of the existing cultural norms, including, above all, the official language.

A special manifestation of the minoritarity is the output of Horst Bienek-a German-speaking Silesian, who repeatedly refers to the category of minoritarity. This study focuses on the issue of language in the novel The First Polka, which opens his so-called Gliwice tetralogy. The way in which the writer refers to the dominant language and sound layer is in many respects consistent with the schizoanalytical interpretation, which gave birth to this understanding of minoritarity in literary texts.
\end{abstract}

Keywords: minor literature, schizoanalysis, Horst Bienek, minority, minoritarity.

The minoritarian aspect, introduced into philosophical and sociological discourse by Gilles Deleuze and Félix Guattari, has found a particular application in contemporary literary studies. Based on the works of Franz Kafka, the founders of schizoanalysis formulated a catalogue of standard characteristics 
of works that fit within the diversified stream of minor literatures. In their view, the writers' specific social and political position has become a factor determining the unique poetics and composition of works that contradict the interpretation characteristic of "great" literatures. The open conflict between the minority and the majority restricting the former's rights was expressed directly in Kafka's early notes, in which the author unknowingly outlined the framework of the entire current: "What in great literature goes on down below, constituting a not indispensable cellar of the structure, here takes place in the full light of day, what is there a matter of passing interest for a few, here absorbs everyone no less than as a matter of life and death".

At the basis of minor literatures, there are countless different conflicts and tensions that lead to the reversal of poles and hierarchies. What constitutes the "lower orders" in the official culture, insignificant details and nuances, in the minority culture becomes a dominant feature, the only possibility to come into contact with the Real ("the universal sentence on the life and death of all"), which in the official sense will never be available, will always be hidden under the cover of a "temporary concourse", that is the most stereotypical and vulgar emanation of the Imaginary. These initial oppositions lead to the opening of a plan that escapes traditional perception: being-a-minority, which determines the existence of the category of minority, is not only a social or political reflection. The two factors only induce the development of minoritarian traits, while the minoritarity itself is ontologised and happens in an ontological perspective. Above all, minoritarity gains linguistic traits, and from the dominant language at that, or rather makes advanced transformations of the latter its basic activity.

Kafka (in schizoanalytic terms, the Kafka-machine) - a German-speaking Jew who lived in Prague - served Deleuze and Guattari as an ideal model for the author of a minor literature. He was a representative of a minority that experienced ever greater repression, he created works in the language of majority, works that were clearly different from the current poetics and referred to the crisis of assimilation, as confirmed by Max Brod in his commentary on Kafka's novels. ${ }^{2}$

The creation of this machine is primarily the result of a specific combination of languages and discourses that decide about the possibility of the existence of minor literatures. Formal membership of a minority or bilingualism that consists in the using at home a language other than the official one

1 F. Kafka, Diaries, trasl. M. Greenberg, New York 1949, p. 194, as cited in: G. Deleuze, F. Guattari, Kafka: Toward a Minor Literature, transl. D. Polan, Minneapolis, MN, London 1986, p. 17.

2 See: F. Kafka, Amerika, Frankfurt am Main 1976, p. 261; B. Neumann, Franz Kafka: Aporie asymilacji. Rekonstrukcja tryptyku powieściowego, transl. S. Mrożek, Wrocław 2012, p. 24. 
is not in itself sufficient to recognise such inclusion. Deleuze and Guattari notice Kafka's unique position: "Now something happens: the situation of the German language in Czechoslovakia as a fluid language intermixed with Czech and Yiddish, will allow Kafka the possibility of invention". ${ }^{3}$ In order for a language to develop (or rather invent) a writer of a minor literature, it has to experience many aspects of minoritarity itself, reach the point of its own disintegration in the way in which the language of the Prague German-speaking minority disintegrated under the influence of many social and linguistic factors. Only this complicated network - a language that is removed from its basic task (given the perspective of great cultures), i.e. the creation of sensescreates a code capable of reaching the Real. It passes through the threshold of deterritorialisation without the need for re-territorialisation, i.e. re-integration into a structure, and thus escapes from symbolisation and is able to operate on pure, real values:

Ordinarily, in fact, language compensates for its deterritorialization by a reterritorialization in sense. Ceasing to be the organ of one of the senses, it becomes an instrument of Sense. And it is sense, as a correct sense, that presides over the designation of sounds (the thing or the state of things that the word designates) and, as figurative sense, over the affectation of images and metaphors (those other things that words designate under certain situations or conditions). ${ }^{4}$

The same combination of social and linguistic factors may also be observed in another area of influence of German culture, namely Upper Silesia before World War II. Horst Bienek presents an exceptional picture of the formation and duration of minoritarity understood in this manner. The author of Gliwice tetralogy occupies an even more unique position. As a German speaking German in the German part of Upper Silesia, he formally remained a representative of the dominant culture. What is more, he motivated the decision to leave Gliwice in 1945 with the prohibition on using the German language imposed by the Polish authorities. Nevertheless, his language (and consequently his perception of reality and self-determination) remained a separate entity, deeply experienced in many minoritarian aspects. In fact, all of Bienek's novels-focused primarily on the question of identity - are an intensive search for breaks within language, an attempt to render its various intensities and destabilising factors. Silesianness is inseparably connected with this language-chopped together with Polish lexemes and syntactic variations - and it becomes a fundamental dominant feature of the writer's mature creative period.

In his most famous novel, The First Polka, this minoritarian factor seems to unconsciously control the characters and lead the action of the work to the climax of the wedding scene, during which there are several "lessons in being

3 G. Deleuze, F. Guattari, op.cit., p. 20.

4 Ibidem. 
a minority". The ceremony, which, in Valeska Piontek's opinion, should unite the cream of Gliwice society, in reality turns into an open confrontation between Silesian people and Germans originally from the inland of the country. During Irma's wedding-party, the process of colonisation - or rather re-colonisation motivated by the beginning of war-until now unnamed and hidden, becomes exceptionally clear and painful (World War II begins during the wedding. When guests leave Haus Oberschlesien, they see that soldiers have disappeared from the streets of the city, having set off towards the border.)

Undoubtedly, the central conflict of the work is a complicated relationship between the representatives of the majority and the minority. While the definition of the former is not particularly demanding (it will be German or, to a much lesser extent, Polish statehood), the minoritarian aspect is much more difficult to recognise. As in the case of Bienek himself - who formally belongs to the dominant culture - most of the protagonists of The First Polka became well adapted to the German statehood, speak German, and are able to function even in the difficult realities of the Nazi system. In this last respect, the model couple is the enterprising Valeska Piontek and her brother Willi Wondrak, who joins almost all national socialist associations (without the NSDAP party!) and is successful in business. Valeska's children follow the same pattern: her son Josel, who actively participates in the meetings of Hitlerjugend, and her daughter Irma, who marries a Wehrmacht soldier that came from the heart of the Reich. The only evidence of belonging to a minority are certain hidden details, which become apparent only at the moment of violent confrontation with the majoritarian apparatus.

This is particularly evident in the linguistic perspective, which suddenly turns out to be a source of certain aporias. During the wedding, representatives of the minority - suspended between the German and Polish poles - are publicly making a linguistic declaration, which is an open political manifesto:

"You laugh at the names of few town and villages", the priest continued, "because your awkward tongues handle them so clumsily. But, gentlemen, remember, this is a region which has grown up historically between Teutons and Slavs, Germans and Poles, and each of those names bears witness to this... [...]".5

In the understanding of the representatives of the Silesian option, this separate, complicated language - mocked by the German majority-is devoid of a logical, sense-forming function. It is here that the minoritarity is born, declared by the priest who is then followed by Valeska and other Silesians. Foreign phonemes, in a strange way sanctioned by the dominant German language, transform into a set of sounds read in an intuitive way. In her mind, Valeska, who is a piano teacher, transcribes them to a score:

5 H. Bienek, The First Polka, transl. R.R. Read, San Francisco 1984, p. 196. The page numbers given in brackets in the main text are in accordance with this edition. 
For someone who has grown up here and who must live here, and who likes living here - you won't be able to grasp this — the names are like music. [...] Shall I tell you all the places I've been? Oh yes, listen to the music of these words: I have been in Budtkowitz, in Jellowa, in Knurow and in Laurahütte, in Malapane, in Gogolin, Zaborze, Miechowitz and Groshowitz, in Maltschaw and in Leobshütz, in Deschowitz and in Krappitz, in Bobrek-Karf, in Potempa, in Kulisch, in Pitschen, in Bielitz... Let me think of some more, in Straduna, Rybnik, Niewodnik, in Leschnitz, Patschkau, Peiskretscham, in Zernitz, Jasten, Korkwitz, in Ostrosnitz, Nieborowitz, Wischnitz, in Zawada... [p. 196]

"You would be surprised, Herr Direktor"- the priest's voice returned to normal- "how often these names even have a patriotic, a German patriotic history, which does honor to our state of Prussia. Yes, Sergeant, one must love this land, this language... these people, in order to understand all that" [p. 197].

However, in this very clear scene, which serves as an obvious manifesto, something happens that is unexpected and impossible to appear in any other system. Toponyms, i.e. the most territorial units, which are the clearest manifestation of the multilevel symbolisation imposed by the dominant culture (which first imposes territorial inscription through literal grooving in the ground during the settlement process and then arbitrarily includes the territory in a symbolic code by assigning a name to it) become, in a minoritarian view, peculiar anti-units, that subvert the signifying system.

There is a double looping here. First of all, within the language code, the Germanised names of the towns, which still hold revolutionary, minoritarian potential, reveal their own language code, thus selling off the entire dominant culture, which is easily felt by both sides of the emerging conflict. Secondly, these units, designed to control and prioritise, that is simply to signify, leave the symbolic code behind in a strange way. Thanks to their minoritarity, they penetrate into the Real, cease to be a language, and begin to be not so much music as a set of simple sounds opposing music and any form of structuring (Valeska hits a non-existent keyboard with her fingers and screams: "Yes, this language must be sung!" [p. 196]).

Deleuze and Guattari reflect this mechanism very clearly: "The sound or the word that traverses this new deterritorialization no longer belongs to a language of sense, even though it derives from it, nor is it an organized music or song, even though it might appear to be". ${ }^{6}$ While the former is clear to both sides, the latter remains an immanent characteristic of the minority. The whole conflict - which is in fact the central conflict of the book-begins at the moment of the unsuccessful sexual colonisation, which develops in parallel and actually constitutes an equivalent dominant feature of the novel (as evidenced by the fact that Irma's wedding with the soldier she met a week earlier was placed centrally in the text). A drunken Sergeant, a representative of the

6 G. Deleuze, F. Guattari, op.cit., p. 21. 
apparatus of repression quartered in the Pionteks' house, cannot communicate with the woman with whom he dances, which causes waves of laughter among other Germans from the heart of the Reich:

"Father", the Sergeant said in his cold, foreign voice, "it's a strange world. Help me! I'm dancing with a girl, she's from Biskupitz. Biskupitz!” He tugged Lucie (Widera) over to him and displayed her like a circus barker showing off a freak: the girl with two heads. "From Biskupitz", he repeated, "have you ever heard such a name before...? Biskupitz! I dance with a different one, she's from Schi... Schi... she's from..., well, Schimischow, I dance with a woman who is from Ujest..." [p. 194].

Immediately after the debate between the majority and the minority, there is a no less important scene of toasting. Besides the patriotic calls of Miss Willimczyk ("To our Pfarrosch, to our Silesian word-music!" [p. 197]) and Willi Wondrak ("To our small, narrow world, and may a little piece of it belong to us!" [p. 197]), we can also hear voices of the opposition, such as the resigned Sergeant ("To this stinking world! To this stinking world! To this stinking world!" [p. 198]) and Count Magistrate ("To the world of Satan that awaits us!" [p. 197]), who predicts Hitler's extermination. However, the foreground is dominated by the voice of Valeska's sister-in-law, rebellious Milka. Her cry "to the Mississippi!" [p. 197] becomes an aleatoric deconstructor of both plans, the purest manifestation of minoritarity, opposing any attempt at assigning her to any given category. Only Milka, who openly cuts herself off from the social agenda by living in a barrack near Klodnitz (Kłodnica), represents a minority in its own anti-symbolic way: during the wedding, she not only distances herself from the obvious majority, i.e. from German officials and soldiers, but also from the capitalist machine, which unexpectedly comes from the minority centre and threatens Milka's subjectivity: Valeska, convinced of her own good nature, proposes to join her. Defiant Milka, mainly occupied with cigar making, rejects this offer as impossible and decides to become a maid in waiting to a rich countess. For she realises that it is impossible to be a capitalist minority (“'Don't you simply want to get me away from the river, Valeska?' [...] 'Leave me by the river, I need it." [p. 192]). The penetration into the body of capital (which is perfectly illustrated by the movements associated with the coming war) is always a kind of betrayal. It is committed especially by Valeska, who speculates on the land trading it even with the Church.

The very cry of "to the Mississippi" seems to be a kind of paranoid sinthome - the Real shining through, not referring to anything. It rebels against the power of meaning just like the minority rebels against the majority. In the cry "to the Mississippi" there is therefore no reasoning we would like to find by following the logical premises, that is premises located within the logos. In this unexpected scream, however, lurks the truth of a different, non-Heraclitic order: Milka throws a pure difference into the system - a phonetic record of 
her own desire, a river of rivers, whose waters become a fetishised phallic object for her and in such a form they tear apart the structures created by two dominant centres: first the fascist apparatus of the state and then - unconsciously - the seemingly minoritarian capitalist machine launched by Valeska and her brother.

The way in which a minority processes the language of the majority leads to a variety of phenomena that escape classical perception. The fundamental right of a minority is its unpredictability, its ability to fragmentise, deconstruct, and create its own systems. These, in turn, enable the delimitation and demarcation of secure borders. The First Polka is filled with attempts of this type. The tissue of the German language is torn apart by numerous Polonisms and regionalisms, the way of pronunciation and dialecticity allow us to recognise the Other and to shelter from a possible threat. Perhaps this phenomenon of Deleuzian minoritarity - the phenomenon of the internal formation of language, which on this preontological level is a real thing (das Ding), and only later, through symbolisation, acquires a specific form, is rendered in Paul Celan's poem À la pointe acérée in a unique form, in which "unwritten things harden into language" ("Ungeschriebenes, zu / Sprache verhärtet [...]") 7 . Derrida interprets them as follows: "Without writing, non-written, the unwritten switches over to this question of reading on a board or tablet that you perhaps are. You are a tablet or a door: much later, we will see how a word can address itself, indeed, confide itself, to a door, hinge on a door opened to the other". ${ }^{8}$

This encounter with the real-available in the schizoanalytical concept only to representatives of minorities - creates a practically unlimited plane of transformations. One of these transformations is the syllable language used by Josel and his neighbour Ulla to hide from the majority:

Ulla giggled. Then she looked at Josel and began: "Wherbsen Erbsen Rerbsen Erbsen kiks Herbsen Arbsen Verbsen Erbsen kiks Yerbsen Urbsen kiks Berbsen Erbsen Erbsen Nerbsen?". And at a tempo that made Andreas stare at her wideeyed.

Josel answered just as rapidly: "Irbsen Nerbsen kiks Therbsen Erbsen kiks Jerbsen Orbsen Herbsen Nerbsen". And only now did Andreas realize that he could not understand a word they were saying.

Ulla has just begun to describe a visit to the Admiral's Palace in Hindenburg where Bernhard Eté had played and Rosita Serrano had sung - and now it was spoiled; she was talking with Josel in this idiotic... gibberish [p. 161].

7 P. Celan, À la pointe acérée, cited in: J. Derrida, Shibboleth. For Paul Celan, in: idem, Sovereignties in Question. The Poetics of Paul Celan, transl. J. Wilner, eds. T. Dutoit, O. Pasanen, New York 2005, p. 3.

8 Ibidem. 
Andreas, who comes from Breslau, does not understand the "Erbsen language" [p. 162-163], which Josel derives great joy from. There is no doubt, however, that he is not a complete representative of the dominant culture. Ulla states: "Andreas is a pierunnik, he's not like the others who come from the Reich... He could be one of us" [163]. The membership of a register is determined by phonological matters: "He's getting along so well that we'll soon have him rolling his $r$ 's like us". "[...] 'Soon he'll be able to say pjä-rrunn-je right', will pronounce 'pierrunie' well” [p. 163]. It is therefore the minority's right to create shibboleths that distinguish it from the threatening majority. The typical Silesian word pierunie, which Germans from inland Reich are not able to pronounce due to the hard $r$, is what Derrida has in mind, when he states that "one must pronounce shibboleth properly in order to be granted the right to pass, indeed, the right to live". ${ }^{9}$ Andreas can join the minoritarian community, can reject the molecular block, but must first penetrate the plane of the language. In the end, he actually does it. After Irma's wedding, in a conversation with Valeska, he states - imitating Josel's favourite saying - that it was fantastischnek [p. 245]. Thus he passes the shibboleth test, acquires the right to "pass, indeed, the right to live", and becomes a member of the Silesian minority.

Among the guests gathered at Hotel Upper Silesia (Haus Oberschlesien), there are three people who do not fit into the dichotomous division: two schizoid individuals (Milka, mentioned earlier, and the Wild Monk-an emotionally disturbed tramp, mad monk, former patient of a mental hospital) and County Magistrate Montag, a mentally stable individual, but deeply tried by his own minoritarity, or rather by the repression of that minoritarity.

The elderly man, officially classified by the Nazi apparatus as a half-Jew, represents a unique case of minority and aporia of assimilation-his story clearly corresponds to the history of Kafka. Not only are the individual biographical facts the same, but also the attitude to the issue of identity, and the breakdowns in the process of its formation.

First of all — which Bienek meticulously ensured - Montag and Kafka constitute a certain unity in the textual and symbolic dimension, which transforms the former into a model writer of a minor literature. He can be interpreted in this respect as an attempt to transfer Kafka to a time that he could only anticipate but, for obvious reasons, could not experience. The double Montag-Kafka-machine is forced into double hiding. Montag goes from an official register in which, like Kafka, he leads the life of a valued lawyer to a sub-register hidden

$9 \quad$ Ibidem, p. 1. 
within a different minoritarity: he rents a small garden house from Valeska and almost completely dissociates himself from social life to devote himself to creation.

A key role in the interpretation of this figure is played by the attitude to Kafka's famous Letter to His Father. Actually, the choice of a model for reading this work determines the appropriate way of perceiving not only the writer's work, but above all the minoritarian aspects as such. In the traditional interpretation, the figure of the Father to whom the letter is addressed functions as a despotic "master boss". The factors that evoke a sense of trauma and enslavement are, therefore, the traits usually attributed to Oedipus, with particular emphasis on the paranoid need to control every movement of individuals enclosed within a family triangle. According to the latest studies quoted by Bernd Neumann, the crisis of Kafka's figure of the Father, however, concerns completely different factors. It is primarily related to the ineffective and paranoid attempt at radical assimilation. It turns out that Kafka's problems with coping with his own life are the result of the non-verbal transfer and internalisation of the hidden second plane of his father's personality, namely uncertainty as a consequence of his unprocessed social advancement. ${ }^{10}$

The Father's motivation is essentially positive. As a representative of an eternally oppressed minority (and, worse still, as an immigrant who cannot identify with the land that has not yet been befriended), he wants his son to enter into the majority and to cut himself off from his burdensome background forever. This is why both Kafka and Montag, against their will, become lawyers and why they blend into bourgeois society, which they despise. This to some extent perpetuates their inner nomadism and rejection of all forms of Oedipal assignment (Kafka will become a figure of the eternal bachelor, Montag - of the eternal widower). According to their fathers, only within such an understanding of success are they able to conceal from socius ${ }^{11}$ the greatest crime against the majority: being a preontological minority.

Thus, the interpretation of their works changes. As Neumann suggests, Kafka's writing may be determined to a much greater extent by the power of social structures interwoven in Father's existence and less by the psychological violence of his Oedipal tyrany. ${ }^{12}$ In fact, Kafka's work, and consequently that of Montag, or Kafka transferred to Nazi times, is not - contrary to the opinion adopted in some circles - a reaction to brutal Oedipal assignment. Instead, it is an attempt to restore the right to minoritarian consciousness, an attempt to correct the mistakes of a father who desperately tried to renounce this consciousness and develop in himself and his children the characteristics

10 B. Neumann, op.cit., p. 29.

${ }^{11}$ See: K. Surin, Socius, in: The Deleuze Dictionary: Revised Edition, ed. A. Parr, Edinburgh 2010, pp. 258-260.

12 B. Neumann, op.cit., p. 29. 
of a dominant culture. It is at this point that assimilation aporias are born, which arise in the texts of the authors of minor literatures in the form of a set of psychological and social traumas.

The school of new historicism represented by Neumann agrees with schizoanalysis with regard to the central idea. It is the social vector (in contrast to the psychoanalytic interpretation traditionally attributed to Kafka's works) that becomes the dominant shaping not only the poetics of works but also the broader epistemological context. This key factor transforms writers into "literary seismographs", i.e. individuals capable of analysing tensions within current discourses and of anticipating new narratives. ${ }^{13}$

Montag is a kind of synthesis of Kafka's minoritarian attributes. Bienek constructs this character in such a way as to bring to the fore a set of factors shaping a specific, minoritarian cognitive apparatus. He recreates his family's journey with particular scrupulousness: "Montag's ancestors had come from far to the east; each generation had moved farther west, always following the sun" [p. 60]. In this movement, from the periphery to the centre, the basic trauma of assimilation and the reckless attempt to gain acceptance in the eyes of socius are reflected. Montag himself is born in Mysłowice, in Prussia, where his father trades in cloth, but his grandfather - a proud Jew from Odessaplays a much greater role in his life, telling the boy "about God in dark, glowing riddles; $[\ldots]$ of the robber chieftain Mendel Krik and his sons Benja and Lwow [...]" [p. 62]. This attempt to cultivate identity is, of course, met with aggression from Montag's assimilated father:

When his father was there he warned the old man not to confuse the child, and he said to the boy, "You shouldn't believe all your grandfathers stories; they're inventions, and besides, that was over a hundred years ago".

I myself believed everything Grandfather said, and one day I set out for Odessa to join Benja Krik's band of robbers, but I only got as far as Schoppinitz, down the road and across the river; the police picked me up there and brought me back home [p. 62].

Montag not only tries to reverse the vector of assimilation (instead of travelling along the east-west line, he chooses to return to the east, that is to the core of his Jewish identity), but also breaks down the narrative. In fragments of Montag's memories, the auctorial narrative, consistent throughout the entirety of Bienek's work, gives way to a first-person narrative, as if only this return to deeply hidden, partly suppressed memories was a true thing, and thus touched the core of Reality, around which minor literature is actually founded.

Jewish memories generate a range of traumatic symptoms noticeable in adult life: Montag remembers the "dark corners of the house in the Horse Market" [p. 62], in which people-survivors of the pogroms of the Jews, on

13 Ibidem, pp. 22-23. 
their way from east to west - narrowed to synecdochic figures: "Sometimes there was nothing there, nothing at all, just the fright, [...] sometimes there was someone lying there, a bundle that moved, a body that groaned, or there were only sounds like a watery litany [...]" [p. 62]. Owing to nyctophobia, which was born then, Montag always sleeps with a light on, which in later life induces the suspicion of the dominant apparatus.

Immediately after his grandfather's death, his father decides to convert to Catholicism. Deprived of his sidelocks, Montag is baptised and-significantly - once again moves west with his family, this time to Wrocław, the capital of the province, where he takes up studies in the Catholic grammar school of St Matthew. Of course, language issues are becoming a fundamental object of social suppression: "And if I said 'kokolores' there, I got a stroke of the cane across my hands, and if I said 'meschugge' at home, my father gave me a rap on the head" [p. 63]. Linguistic and religious issues are inextricably linked to the geographical aspect. Montag's Father, just like Kafka's father, came from the province and wanted to forget "the east", which stores Jewish memories.

After graduating from law school and completing his doctoral studies (sic!) at the University of Wrocław, Georg Montag marries Erika Weinreich from the bourgeois class, and in a church at that. He almost completely "overcomes" his inner minoritarity - he very skilfully pretends to be a true German, a Catholic, and a successful man. Only in dreams do the stories of Mendel Krik and his sons return to him. Despite this radical assimilation, he encounters anti-Semitism. When he becomes an advisor to the district court in Gliwice, a jealous colleague shouts after him: “Jew! [...] This country's run by Jews, but one day it'll all be different, we'll get rid of you all!" [p. 65].

He achieves his greatest successes in Upper Silesia, where apart from the position in the court, he is also a member of supervisory boards of mines, steel mills, and electric power plants, as well as of the parish committee of St Peter and Paul's Church, he participates in World War I, and even wins a second-class Iron Cross. His wife gives birth to a daughter he wants to name Ruth, but is eventually persuaded to choose the names of the Catholic saints Agnes and Elisabeth. Following Erika's death during the second birth, Montag focuses exclusively on raising the child.

Thus, a peculiar double transaction takes place. As a lawyer, on the one hand, he is almost utterly absorbed by the capitalist, Catholic society, forgetting that his father's name was Benjamin Montag and his grandfather was born in Odessa as Moischele Ponedjelnik. On the other hand, he voluntarily suspends his full participation in the socius: from his wife's death he will be a widower only, just as Kafka has been a bachelor for almost his entire life. He himself wrote about this condition in the following way: "[...] he has only one thing always: his pain, in all the circumference of the world no second thing 
that could serve as a medicine [... $]^{114}$. According to Deleuze and Guattari, this specific figure - suspended between nomadism and society — becomes one of the key categories of minor literature: "he doesn't flee the world; he grasps it and makes it take flight on a continuous and artistic line". ${ }^{15}$ This peculiar, voluntary breakaway from the Oedipal triangle leaves room for pure creativity, to which Montag dedicates himself completely. Due to Nazi politics, he also withdrew from his professional life, retires, moves to a house in Valeska Piontek's garden, and desperately tries to finish his life's work: a biography of Wojciech Korfanty.

Korfanty (to whom Montag refers to in his notes as "K", which evokes the model character of Kafka and to some extent his porte-parole) becomes an ideal hero of the minority. These are the traits which Montag points out in his monograph. And it is undoubtedly a direct result of the predefined, somehow preontological function of the "literary seismograph", which he becomes by virtue of his minoritarian position. As the authors of Anti-Oedipus would have it, his literary output is above all "entangled in politics". This politicisation, from which there is no escape, is characteristic of minor literatures and essentially allows the dominants to be reversed. ${ }^{16}$

Before the reader meets Montag, a half-Jewish man hidden in Valeska's garden, he gets to know his political manifesto. This in turn begins with an accusation against any majority, in this case the Polish majority:

By decree of Mościcki, the President of the Polish State, form 1 July 1930 the Sejm was dissolved and that of Silesia adjourned indefinitely. [...] On 10 September 1930, practically all the parliamentary leaders of the opposition parties, 88 in number, were arrested en masse. Among them was Wojciech Korfanty, head of the Christian Democratic Party [p. 28].

Montag does not interpret history as a chronological record in which cause and effect sequences play a decisive role. In his interpretation, it transforms into the "legislative body" known from the concept of Michel Foucault, which "sends a set of concepts into a set of forces, so as to assign to each concept the force or forces that created it". ${ }^{17}$ All the work will, therefore, be nothing more than a collection of traumas, the true experiences of being a minority, which Montag and his family have experienced and which he also notes in the context of the repressed Silesian minority. In order to learn how the mechanism of this terror works, he goes back to the period of serfdom, which-in his opinion-determines the specific location of the Silesians and motivates

14 F. Kafka, Diaries 1910-1913, transl. J. Kresh, ed. M. Brod, London 1948, p. 26.

5 G. Deleuze, F. Guattari, op.cit., p. 71.

16 Ibidem, p. 17.

17 M. Podniesieński, Prawda i władza. Myśl Michela Foucaulta w latach 1956-1977, Kraków 2012, p. 100. Translation-K.S. 
numerous revolts and rebellions in the eighteenth and nineteenth centuries. Unfavourable economic conditions, i.e. the "masked" serfdom of peasants that lasted until 1918, are translated into the shaping of minoritarian traits, and the capital itself is transformed into one of the factors determining exclusion ("It was important to know this in order to understand K" [p. 109]). Montag sees this crisis and, according to the principles of Foucault's genealogy, inscribes it in the context of collective trauma: "While Marx and Engels were drawing up the Communist Manifesto on behalf of the 'League of the Just', the peasants on the right bank of the Oder were still living as serfs, the only ones remaining in Prussia. Would not that (and even more so, the Bismarckian Kulturkampf) have had to produce a K?" [109].

$\mathrm{K}$ (orfanty) is, therefore, born at the point of economic repression. In the same place - although in a way à rebours - K.-porte parole of Kafka is also born. In his case, however, the pole of capital is being reversed: were not the financial successes of the Jews one of the main motivators of anti-Semitism? Does not Montag himself experience painfully the same aggression when he hears from his colleague "Jew! [...] This country's run by Jews, but one day it'll all be different, we'll get rid of you all!'? The logic of the majority's attitude towards minorities oscillates around two poles: the majority cannot stand the minority when it is clumsy, so it leads to its economic destruction and enjoys its further humiliation (the Silesians are the only [sic!] group that lives in proper serfdom until the end of World War I), but it hates the minority even more when it achieves success. In the first case, this leads to a sudden increase in revolutionary energy: ostracism gives birth to Korfanty, the subversive leader of the armed uprising. The reaction to the second type of repression is less visible, but no less traumatic. Rejection in spite of success, and therefore completely unjustified rejection in spite of an ideally conducted attempt at assimilation, is responsible for shaping the primordial, inexplicable fear that accompanied Kafka and that destroys Montag's life.

Montag meticulously recreates the story of K. He presents a whole series of socio-political phenomena that transform him first into a minority hero (winning an election to the Reichstag, the success of the Third Silesian Uprising, of which he was a leader), and then into the enemy of the majority (the failure of his government in connection with Piłsudski's protest, his detention in the Brest Fortress and Pawiak prison, and finally — as suggested by Montag, referring to the incomplete notes of the Polish historian - a murder commissioned by Piłsudski's followers). Equally important is the analysis of the discourses to which Korfanty was subjected, but which he also shaped himself to the same extent as the editor of Polish and Christian magazines.

It seems that the genealogical approach, in which history is only a matrix for making decisions, focusing on unique traumatic events and the accompanying discourses, sanctions a kind of universalism of minor literatures (it is not without reason that Deleuze and Guattari draw attention to their multiplicity 
and diversity). The reader cannot be surprised that such an unpopular and dangerous subject (Montag's work is carefully watched by functionaries and party officials) is chosen by a representative of a radical minority, a minority motivated by political, ontological, and social considerations. His situation, that is, the situation of a Jew in a Nazi state, actually corresponds to the situation of Korfanty in the authoritarian Polish state of Piłsudski or Kafka at the end of the Austro-Hungarian Habsburg period. The differences between them concern only (although the word only sounds cruel from the perspective of upcoming traumas) the possible assortment of repressive measures, for which the minority must always be prepared. It is precisely the state of this readiness and constant threat, which force unsuccessful attempts at assimilation and the resulting deepening of alienation, that are responsible for the development of the dominant features of minor literatures.

Of course, Montag's work, unlike Kafka's works, is a pure interpretation of minoritarian aspects, devoid of Derridean veils [voiles] that would represent the artistic style in such a system. Their motivation to write, or rather a certain preontological necessity to create, seems to be the same. This specific kind of creativity is "a minor practice of major language from within, the only way to express a collective voice". ${ }^{18}$ This is why Montag cannot help but get involved in his work:

He wasn't quite sure, but somehow he felt that his sentences were acquiring a more and more sentimental tone, ever since he had begun to concern himself in this chapter with K's persecution, his arrest, and his humiliation.

$[\ldots]$ the further and deeper he drifted into Wojciech K's biography, the more it confused him. K's scintillating personality certainly has something to do with it, as did the (sometimes surprising) shifts in his political position - but he himself lacked the resoluteness with which he had judged and analysed K's actions in the beginning. And again he was filled with doubts, as so often in the past weeks and months, as to why he had undertaken this project at all [p. 29-30].

Montag thus reveals the extraordinary practice of the authors of minor literatures. His doubts are completely natural: his work consumes almost all of his life and is deadly dangerous for him, because due to his attempts to borrow Polish books and his correspondence with Polish historians, he is noticed by the apparatus of repression, and at the same time he has no chance of publishing the work. Montag knows perfectly well that he only writes it in order to later bury it in the garden. Nevertheless, he spends nights on a bundle of loose pages, covers the windows with curtains, so that no beam of light would get out on the streets to betray him.

18 G. Deleuze, F. Guattari, op.cit., p. 18. 
If one can compare the act of minoritarian writing to anything, it can only resemble fasting. As Deleuze and Guattari point out, "Disjunction between content and expression. To speak, and above all to write, is to fast". ${ }^{19}$ That is why the role of the model protagonist of the minor literature was given to Kafka's starveling, whom the creators of schizoanalysis prefer to call "Master of fasting". The ascetic Montag is analogously the master of this exhausting struggle. He draws the curtains apart "only far enough to let in the light he needed. He did not want to look outside at the green, the trees stretching their leaves towards his window; nature, he could not think why, was suddenly repugnant [...]" [p. 109], he terrifies people with his skinny, sickly physiognomy. He isolates himself in order to write, fasts because it is the only modus operandi available to the minority.

The Crystal Night is a turning point in Montag's life. He is shaken by the sight of the burnt down synagogue and the growing anti-Semitism. The return to the minority, the final rejection of ineffective assimilation, once again goes through the dimension of sound: "And underneath all the Catholic prayers, litanies, and credos he had learnt, he now pieced together fragments of the Kaddish [...]" [p. 112]. He finally confesses his family's story to himself, recites it as Kafka could recite his letter to his "dearest father"20 — not only with reproach, but also with a humble admission of his attachment to the minority and a sense of shame about the failed attempt at assimilation. Montag says to himself: "[...] perhaps you didn't understand the sense of the words, but remember their melody, wasn't this how it went? Shma Yisrael Adonai Eloheinu Adonai Echad. Yahweh, the God of the Jews, is thy God too!" [p. 113], and then cuts out a tallit and tefillin, although he does not remember how to wear them.

In order to become truly minoritarian, the sounds of Shma Yisrael must pass through one more threshold of deconstruction in exactly the same way as the names of Silesian towns and cities enter the register of the Real thanks to the sinthome of "Mississippi". This clash with the Real is Montag's death that crowns the novel. After helping Josel, who just killed Sergeant in Ulla's defence, he locks himself in his house and listens to the sounds of detonation coming from the Polish border. The narrator's attention then moves inside Valeska's house: German soldiers come to find Sergeant and her son-in-law, who did not appear in their units: "Then a shot rang out on the other side, in the garden, a dry bang, entirely without echo. In that instant a scream broke out which had been locked in Valeskia's throat since the first loud noise" [p. 292]. The landlady does not know what happened. After some time she goes out into the courtyard with the soldiers and sees the broken door to Montag's apartment. At first, she accuses the soldiers of murder, but they tell her

19 Ibidem, p. 20.

20 F. Kafka, Letter to His Father, transl. E. Kaiser, E. Wilkins, London 1966, p. 7. 
that Montag took his own life. She does not believe them and asks them to let her see the body. It is only when she sees a shattered skull and a gun in his hand that she begins to believe in suicide, the perspective of which she has been trying to distance herself from for a long time.

Of course, it is difficult to say whether the version of events given by German soldiers is true. Just before the gunshot, the narrator parted with Montag. He focuses on his hand, in which he holds a paper flower given to him by Josel. This innocent ornament, like the objet petit $a$ that is eternally present and refers to the desire, can symbolise the weapon that will soon appear in the counselor's hand. It will allow for an outlet of his destrudo, the death energy proposed by Eduardo Weiss, which - empowered by secondary narcissism, i.e. the transfer of libidinal energy from external objects to the subject himself-turns against him. ${ }^{21}$ Perhaps Montag reached his final form: he completed and buried the manuscript, saved the boy's life, saw the shadow of a war that would cruelly deal with minorities, so he came into contact with the final Thing and, to put it bluntly, saw no need to continue to sustain his existence. Not only did he fill himself up, but he also crossed the threshold of subjectivity. The suicidal step, expressed by the sinthome of the "dry bang", is a confirmation of this understanding: it becomes a passage à l'acte enabling the transition to the Real. ${ }^{22}$

The attempt to read selected motifs from Horst Bienek's The First Polka presented here allows us to see the most important features of the perspective of a minority (i.e. the category of minoritarity emphasised at the very beginning of this paper) and the "production process" of an artistic work characteristic of it. The starting point is the social position of the writer and his attitude towards the dominant system. This dependence determines the specific construction of the work in an unusual way. Minoritarity is reflected in all layers of the work: it forces not only a specific social and political judgment, not only a strictly narrow model of shaping literary characters and selecting events, but above all a revolutionary approach to the issue of the language itself and the culturally modified image of the shape of culture.

It is this last issue - in a way removed from the formal side of being a minority and devoid of any direct evaluative function - that should be considered a dominant feature of this current. As proved by Deleuze and Guattari,

21 H.A. Rosenfeld, Impasse and Interpretation: Therapeutic and Anti-Therapeutic Factors in the Psychoanalytic Treatment of Psychotic, Borderline, and Neurotic Patients, London 1987, p. 126.

22 See S. Žižek, Courtly Love, or Woman as Thing, in: idem, The Metastases of Enjoyment: Six Essays on Woman and Causality, London, New York 1994, p. 93. 
language becomes an independent character of minor literatures, an object and a tool of deconstruction, thanks to which it is possible to reach what can be described as the "core of minoritarity", i.e. a certain preontological element that transforms the writer into a "literary seismograph", a machine sensitive to current and upcoming changes and overcoding.

A comparative analysis of Bienek's works confirms, first of all, the need for further research into the phenomenon of minoritarity and its literary legitimacy. This research is sanctioned, in a sense, by the immanent pluralism marked in the name of the trend (minor literatures always appear in the plural). This approach makes it possible to work out - as suggested by Kafka himselfcommon categories connecting the minoritarian apparatus of perception. Apart from linguistic and compositional issues, it undoubtedly includes a common philosophical ground, based primarily on the category of emptiness, which occupies a central position in the works of both authors of minor literatures and poststructuralist thinkers.

Translated by Kaja Szymańska

\section{Literature}

Bienek H., The First Polka, transl. R.R. Read, San Francisco 1984.

Deleuze G., Guattari F., Kafka: Toward a Minor Literature, transl. D. Polan, Minneapolis, MN, London 1986.

Derrida J., Shibboleth. For Paul Celan, in: idem, Sovereignties in Question. The Poetics of Paul Celan, transl. J. Wilner, eds. T. Dutoit, O. Pasanen, New York 2005, pp. 1-64.

Kafka F., Amerika, Frankfurt am Main 1976.

Kafka F., Diaries 1910-1913, transl. J. Kresh, ed. M. Brod, London 1948.

Kafka F., Letter to His Father, transl. E. Kaiser, E. Wilkins, London 1966.

Neumann B., Franz Kafka: Aporie asymilacji. Rekonstrukcja tryptyku powieściowego, transl. S. Mrożek, Wrocław 2012.

Podniesieński M., Prawda i wtadza. Myśl Michela Foucaulta w latach 1956-1977, Kraków 2012.

Rosenfeld H.A., Impasse and Interpretation: Therapeutic and Anti-Therapeutic Factors in the Psychoanalytic Treatment of Psychotic, Borderline, and Neurotic Patients, London 1987.

Surin K., Socius, in: The Deleuze Dictionary: Revised Edition, ed. A. Parr, Edinburgh 2010, pp. 258-260.

Žižek S., Courtly Love, or Woman as Thing, in: idem, The Metastases of Enjoyment: Six Essays on Woman and Causality, London, New York 1994. 